\title{
INTERNALISASI NILAI MODERASI MELALUI PENDIDIKAN AGAMA ISLAM DI PERGURUAN TINGGI UMUM
}

\section{INTERNALIZING MODERATION VALUE THROUGH ISLAMIC RELIGIOUS EDUCATION IN PUBLIC HIGHER EDUCATION}

\author{
Yedi Purwanto $^{1 *}$, Qowaid ${ }^{2}$, Lisa'diyah Ma'rifataini ${ }^{3}$, Ridwan Fauzi ${ }^{1}$ \\ ${ }^{1}$ Institut Teknologi Bandung, Jl. Ganesha No.10, Lb. Siliwangi, Kecamatan Coblong, Kota Bandung, Jawa Barat 40132 \\ ${ }^{2}$ IAI Nasional Laa Roiba Bogor, Jl. Setu, Leuwimekar, Kec. Leuwiliang, Bogor, Jawa Barat 16640 \\ ${ }^{3}$ Pusat Penelitian dan Pengembangan Kementerian Agama RI., Jl. M.H. Thamrin No. 6, Jakarta Pusat \\ email: yedi@fsrd.itb.ac.id
}

Naskah Diterima: 29 April 2019; Direvisi: 26 Agustus 2019; Disetujui: 27 Agustus 2019

\begin{abstract}
This article describes the internalization of the value of Islamic moderation through Islamic Religious Education in the general higher education. Religious moderation, including Islam, is important to be internalized, amid the diversity of Indonesian people who have the motto of Unity in Diversity, and in the midst of the development of a dynamic environment that can damage the joints of unity because of the wrong understanding. Writing from the results of research located at the Indonesian University of Education (UPI) in Bandung uses a qualitative approach. Data collection is done through observation and interview techniques. This paper shows that the pattern of internalization of moderating values through Islamic Religious Education courses at the Indonesian Education University in Bandung. The material is adapted to student input, the competence of lecturers and subject matter support from the UPI campus environment. The curriculum is designed according to the provisions of the College. The internalization method is done through face-to-face meetings in lectures, tutorials, seminars and the like. The evaluation is done through screening Islamic insights in an orderly and written periodic report from lecturers and tutors.
\end{abstract}

Keywords: Curriculum; Evaluation; Internalization; Islamic religious education; Moderation

\begin{abstract}
Abstrak
Artikel ini memaparkan internalisasi nilai moderasi Islam melalui Pendidikan Agama Islam (PAI) di Perguruan Tinggi Umum (PTU). Moderasi beragama, termasuk Islam, penting untuk diinternalisasikan, di tengah kemajemukan masyarakat Indonesia yang memiliki semboyan Bhinneka Tunggal Ika, dan di tengah perkembangan lingkungan yang dinamis yang dapat merusak sendi-sendi persatuan karena adanya pemahaman yang salah. Tulisan dari hasil penelitian yang berlokasi di Universitas Pendidikan Indonesia (UPI) Bandung ini menggunakan pendekatan kualitatif. Pengumpulan data dilakukan dengan teknik observasi dan wawancara. Tulisan ini memperlihatkan bahwa pola internalisasi nilai-nilai moderasi melalui mata kuliah PAI di UPI Bandung. Materinya disesuaikan dengan input mahasiswa, kompetensi dosen pengampu mata kuliah dan dukungan dari lingkungan kampus UPI. Kurikulum yang dirancang sesuai ketentuan Perguruan Tinggi (PT). Metode internalisasi dilakukan melalui tatap muka dalam perkuliahan, tutorial, seminar dan yang semisalnya. Evaluasinya dilakukan melalui screening wawasan keislaman secara lisan dan tertulis secara laporan berkala dari dosen dan tutor.
\end{abstract}

Kata Kunci: Evaluasi; Internalisasi; Kurikulum; Moderasi; Pendidikan agama Islam 


\section{PENDAHULUAN}

Persoalan yang menimpa bangsa Indonesia semakin hari semakin kompleks dibandingkan masa-masa sebelumnya. Hampir semua aspek kehidupan mengalami permasalahan, seperti aspek kehidupan agama, pendidikan, politik, hukum, sosial, budaya, ekonomi dan aspek yang lainnya. Pendidikan sebagai aspek yang fundamental juga tak luput dari permasalahan. Hal di atas diperparah dengan terjadinya degradasi nilai moralitas bangsa yang sangat mem-prihatinkan. Di samping masih sering terjadinya perkelahian, kerusuhan, tawuran antar pelajar dan mahasiswa yang sangat meresahkan, tidak kalah pentingnya adalah masalah moderasi beragama yang juga masih perlu ditingkatkan.

Hal ini antara lain dibuktikan adanya sikap dan perilaku intoleran dalam kehidupan beragama dan bermasyarakat. Masih terdapat kantong-kantong intoleransi, kerawanan konflik komunal, dan elemen radikal, yang harus terus diperbaiki. Termasuk di dalamnya adalah masalah intoleransi beragama atau dalam aspek yang lebih luas, keharmonisan atau kerukunan hidup beragama. (Kompas, 2013). Masa depan toleransi di Indonesia tampaknya masih jauh dari kesempurnaan. (Kholid, 2013)_Sejumlah penelitian dan kajian menunjukkan masih adanya gejala intoleransi di masyarakat, seperti yang terjadi di kalangan mahasiswa dan pelajar. Misalnya hasil survei Lingkaran Survei Indonesia yang mengemukakan bahwa sebanyak $31 \%$ mahasiswa tidak toleran. (Etikasari, 2018; Ma'arif, 2019).

Jika kondisi ini tidak segera ditangani maka boleh jadi Indonesia terutama generasi mudanya akan menjadi sasaran empuk agenagen propaganda anti moderasi beragama. Padahal mereka seharusnya menjadi generasi penerus perjuangan bangsa dalam melanjutkan estafet pembangunan Negara Kesatuan Republik Indonesia yang memiliki semboyan yang indah. Semboyan bangsa Indonesia adalah Bhinneka Tunggal Ika yang tertulis pada lambang Garuda Pancasila. Generasi muda Indonesia pada 2030 idealnya bisa memetik secara positif bonus demografi, melihat kuantitasnya yang demikian banyak.

Idealnya semua komponen masyarakat dapat mengambil peran penting untuk dapat mnyelesaikan berbagai problem tersebut. Salah satunya adalah mahasiswa yang sedang menuntut ilmu di Perguruan Tinggi (PT) di berbagai jenis, jenjang, dan lokasi. Mahasiswa sebagai komponen utama penerus pembangunan oleh karena itu perlu dibekali berbagai kompetensi. Bukan hanya kompetensi intelektual yang ditandai dengan kemampuan untuk mendayagunakan nalar dan pemikirannya, tetapi juga kompetensi moral yang ditunjukkan oleh perilaku yang selaras dengan kaidah, norma, kepribadian dan jati diri bangsa. Karena pintar saja tidak cukup, tetapi harus pula berperilaku dan berkarakter baik.

Darmawan dalam Soemantri (2011) mengemukakan bahwa kampus harus berperan sebagai "menara air" bagi masyarakatnya. Kampus mengaliri setiap hikmah bagi masyarakatnya, yang pada akhirnya harus menjadi center of excellance bagi pembangunan. PT sebagai salah satu aktor utama perubahan sosial dalam pembangunan. H.A.R Tilaar (2004) mengatakan bahwa PT adalah pengganti kata hati masyarakat banyak karena tingkat pengetahuannya masih belum mempunyai kemampuan untuk berpikir mandiri. Tanggung jawab moral PT dalam situasi ini merupakan suatu keharusan. Para civitas akademika PT secara keseluruhan bertanggung jawab terhadap perwujudan tanggung jawab moral tersebut. Mahasiswa merupakan pelaku penting dalam menanamkan nilai-nilai moderasi beragama, termasuk nilai moderasi Islam. Penanaman nilai-nilai moderasi Islam tersebut telah dilakukan melalui mata kuliah Pendidikan Agama Islam (PAI) pada Universitas Pendidikan Indonesia (UPI) Bandung.

Berdasarkan latar belakang diatas, rumusan masalahnya adalah bagaimana pola internalisasi nilai nilai moderasi melalui mata kuliah PAI di UPI? Materi apa saja yang disampaikan dalam internalisasi nilai-nilai moderasi melalui mata kuliah PAI?. Bagaimana deskripsi kurikulum dalam pelaksanaan internalisasi nilai-nilai moderasi melalui mata kuliah PAI? Bagaimana metode yang digunakan dalam dalam internalisasi nilai-nilai moderasi melalui mata kuliah PAI? Bagaimana bentuk evaluasi dalam internalisasi 
nilai-nilai moderasi melalui mata kuliah UPI di UPI.

Tujuan tulisan ini adalah untuk memperoleh informasi mengenai pola internalisasi nilai nilai moderasi melalui mata kuliah PAI di UPI, materi yang disampaikan dalam internalisasi nilai-nilai moderasi melalui mata kuliah PAI, deskripsi kurikulum dalam pelaksanaan internalisasi nilai-nilai moderasi melalui mata kuliah PAI, metode yang digunakan dalam dalam internalisasi nilai-nilai moderasi melalui mata kuliah PAI di UPI, dan bentuk evaluasi dalam internalisasi nilai-nilai moderasi melalui mata kuliah PAI di UPI.

Secara teoritis artikel ini bermanfaat untuk mengembangkan kajian keilmuan bidang social religius (agama), terutama pada pendidikan karakter Agama Islam di UPI. Secara praktis tulisan dapat digunakan oleh dunia akademik khususnya Perguruan Tinggi Umum (PTU) dalam melakukan internalisasi nilai-nilai moderasi Islam dalam mata kuliah PAI sebagai upaya mencetak mahasiswa berkarakter moderat di tengah keragaman. Manfaat lainnya adalah untuk meningkatkan kesadaran masyarakat kampus pentingnya PAI dalam memupuk sikap moderat untuk mencegah munculnya paham radikalisme yang berbahaya di dunia kampus, serta sebagai bahan pertimbangan bagi dunia pendidikan tinggi dan pemerintah dalam membuat kebijakan untuk mengedukasi masyarakat kampus tentang pentingnya internalisasi nilainilai PAI.

\section{Konsep dan kajian terdahulu}

Beberapa konsep yang disajikan antara lain PAI, internalisasi, nilai moderasi, kurikulum, dan evaluasi. Sistem Pendidikan Nasional secara tegas menyatakan hak setiap peserta didik mendapatkan pendidikan agama sesuai dengan agama yang dianutnya yang diajarkan oleh pendidik seagama. Pendidikan agama yang dimaksud yakni pendidikan yang bertujuan untuk memberikan pengetahuan dan membentuk sikap, kepribadian, dan keterampilan peserta didik dalam mengamalkan ajaran agama yang dilaksanakan sekurang-kurangnya melalui mata pelajaran atau mata kuliah pada semua jalur, atau jenjang Pendidikan (Ma'rifataini, 2018).
Pendidikan Agama Islam (PAI) pada hakikatnya merupakan proses transfer nilai, pengetahuan, keterampilan dari generasi ke generasi berikutnya yang mencakup dua hal yaitu; pertama, mendidik mahasiswa untuk berperilaku sesuai dengan nilai-nilai atau akhlak Islam, kedua mendidik mahasiswa untuk mempelajari ajaran Islam berupa pengetahuan tentang ajaran Islam.(Sulfemi, 2018). Bagi mahasiswa Islam, maka normanorma tersebut bersumber dari ajaran Islam itu sendiri. Oleh sebab itu maka pembelajaran mata kuliah Agama Islam di PT hendaknya mengacu pada pengajaran yang bercorak Islam yang moderat atau Islam Rahmatan Lil'alamin, bukan ajaran yang mendoktrin mahasiswa menjadi anti toleran dan berpaham radikal. Pembelajaran ini dikenal dengan pembelajaran yang moderat dan bersifat internalisasi, sehingga para mahasiswa bisa mengetahui, menghayati dan bahkan meng-amalkan nilainilai-nilai Islam yang moderat sesuai visi Islam itu sendiri. Adapun visi Islam adalah Rahmatan lil'alamin sebagaimana yang tertuang dalam Q.S. Al-Anbiya [121]:107, artinya: "Tidak Kami utus engkau (Muhammad) melainkan menjadi (bukti bahwa Islam) sebagai Rahmatan bagi segenap alam”.

Internalisasi merupakan penghayatan terhadap suatu ajaran, doktrin atau nilai, sehingga merupakan keyakinan dan kesadaran akan kebenaran doktrin atau nilai yang diwujudkan dalam sikap dan perilaku (Poerwadarminta, 2007). Internalisasi nilainilai agama Islam adalah proses memasukkan nilai-nilai agama Islam ke dalam hati, sehingga ruh dan jiwa bergerak berdasarkan arahan agama Islam. Internalisasi itu didapati melalui pemahaman akan ajaran Islam, kemudian dengan penghayatan yang men-dalam, dan diaplikasikan melalui tindakan nyata.(Muhammad Alim, 2006). Internalisasi menurut Abas Asy-Syafah adalah sebuah upaya pendidikan bagaimana memasukkan nilai-nilai atau pesan-pesan pendidikan kepada jiwa seseorang, mendarah dagingkan nilai-nilai PAI di Kalangan mahasiswa UPI. (Seminar Hasil Penelitian, 2018).

Internalisasi nilai-nilai adalah sebuah proses atau cara menanamkan nilai-nilai normatif yang menentukan tingkah laku yang 
diinginkan bagi suatu sistem yang mendidik sesuai dengan tuntunan Islam menuju terbentuknya kepribadian muslim yang berakhlak mulia. Dalam melakukan upaya internalisasi diperlukan integrasi nilai-nilai pendidikan karakter kepada mahasiswa sebagai peserta didik. Internalisasi bisa terjadi melalui proses pembelajaran dalam upaya melakukan rekayasa mental pada peserta didik dalam hal ini mahasiswa.(Az- Zahra, Setiawan, dan Sabana, 2018)

Nilai secara etimologi merupakan padanan dari kata value. Menurut Kartono Kartini dan Dali Guno dalam Qiqi Yuliati dan Rusdiana (2014) nilai merupakan hal yang dianggap baik dan penting, semacam keyakinan seseorang terhadap yang seharusnya atau tidak seharusnya dilakukan. Menurut Soemantri (1993) mengatakan bahwa "nilai merupakan hal yang terkandung dalam hati nurani manusia yang lebih memberi dasar dan prinsip akhlak yang merupakan standar dari keindahan dan efisiensi atau keutuhan kata hati (potensi)".

Secara etimologis, kata moderat (alwhasatiyah) merujuk pada tiga makna yaitu: pertama, bermakna kebaikan dan keadilan. Kedua, bermakna balance atau seimbang dalam segala hal. Sikap seimbang yang terlindungi dari sikap melebihkan (ekstrem kiri/ifrath) dan mengurangkan (ekstrem kanan/tafrith). Ketiga, memiliki makna berada di tengah atau di antara dua ujung sesuatu atau berada di tengah. tengah antara dua hal. (Dawood dkk, 2017).

Adapun kemoderatan dalam Islam, sebagaimana dikutip Darlis (2007) meliputi : 1) Moderasi Akidah. Adapun moderasi dalam bidang akidah sebagaimana yang diajarkan moderasi al-Asyariah yakni moderasi antara Muktazilah yang sangat rasional dan Salafiyah yang mengedepankan teks tanpa menggunakan rasional. 2) Moderasi hukum Islam. Dalam hal ini, dialektika antara teks dan realitas sejalan dalam mengeluarkan sebuah hukum. Hukum yang ada memberikan kemudahan bagi manusia tanpa melupakan dalil naqli. 3) Moderasi Penafsiran. Tafsir yang digunakan merupakan produk tafsir yang moderat yang berkerahmatan, di mana produk tafsir sesuai dengan nilai keislaman yang tetap memerhatikan kondisi ke-majemukan masyarakat yang majemuk dan heterogen. 4) Moderasi Pemikiran Islam. Hal ini ditunjukkan oleh pemikiran Islam yang mengedepankan sikap toleran dalam per-bedaan, keterbukaan menerima keberagaman, baik beragam dalam mazhab, maupun dalam beragama. 5) Moderasi Tasawuf Moderat. Tasawuf moderat ditunjukkan dengan membangun kehidupan yang penuh dengan kebahagiaan yaitu: kebahagiaan qalbiyah yakni dengan makrifatullah melalui akhlak karimah, serta kebahagiaan jasmaniah dengan kesehatan serta pemenuhan kebutuhan yang bersifat material.

Supaya PAI di PT dapat menjadi sarana internalisasi PAI maka Achmad Tafsir dalam Kama mensyaratkan menyertakan edukasi moral being yakni membiasakan seseorang untuk terus menerus melakukan perbuatan moral, di samping moral knowing. Agar tercipta moral being maka dibutuhkan suasana kelas dan sekolah atau kampus yang kondusif agar nilai moral tersebut dapat diaplikasikan. Tugas seperti itu, menuntut lembaga pendidikan untuk menjadi lembaga pembudayaan nilai moral, bukan hanya lembaga pengajaran moral, dan lembaga pelatihan moral. (Simon, Rath, Hermin,1977; Puerpel, Riyan, 1976, Megawangi, 2005). Maka internalisasi nilai-nilai moderasi PAI perlu diberikan di lingkungan kampus dengan menyinergikan semua komponen kampus, baik software maupun hardware. Kurikulum, dosen, sarana pendidikan, masjid, dan pimpinan PT.

Kurikulum menjadi pusat perhatian para ahli pendidikan, sehingga banyak sekali pengertian tentang kata tersebut sesuai dengan pemahaman dari masing-masing pakar pendidikan. (Wafi, 2017). Kurikulum dalam pengertian yang cukup lengkap sebagaimana didefinisikan oleh Nana Syaodih (1997) yaitu sebagai suatu perangkat pernyataan yang memberikan makna terhadap kurikulum Kemudian secara komprehensif, bahwa kurikulum terbagi menjadi tiga konsep.

Pertama, kurikulum sebagai substansi, yakni sebagai suatu rencana kegiatan belajar atau sebagai suatu perangkat tujuan yang ingin dicapai. Kedua, kurikulum sebagai sistem, yakni merupakan bagian dari sistem 
persekolahan, sistem pendidikan maupun sistem masyarakat. Ia mencakup struktur personalia dan prosedur kerja. Ketiga, kurikulum sebagai suatu bidang studi, yakni bidang studi kurikulum. Tujuannya adalah mengembangkan teori kurikulum dan sistem kurikulum.

Kemudian, Ralph W Tylor dalam Nana Syaodih (1997:29) mengemukakan empat pokok yang menjadi inti dari sebuah kurikulum, yakni tujuan pendidikan manakah yang ingin dicapai oleh institusi pendidikan?, pengalaman pendidikan yang bagaimanakah yang harus disediakan untuk mencapai tujuan tersebut?, bagaimanakah mengorganisasikan pengalaman pendidikan tersebut secara efektif?, dan bagaimanakah kita menentukan bahwa tujuan tersebut telah tercapai?

Pengertian evaluasi menurut Guba dan Lincoln (1985:35) dalam Zainal Arifin (2012: 7) sebagai suatu proses untuk menggambarkan orang yang dievaluasi dan menimbang makna dan nilainya. Kemudian Sax dalam Zaenal Arifin (2012:8) sebagai suatu proses di mana pertimbangan keputusan suatu nilai dibuat berdasarkan berbagai pengamatan, latar belakang serta pelatihan dari evaluator.

Evaluasi dapat dilihat sebagai suatu proses bukan suatu hasil (produk). Hasil dari kegiatan evaluasi adalah kualitas sesuatu, baik yang menyangkut tentang nilai maupun arti. Yang dipelajari adalah memberikan pertimbangan mengenai kualitas sesuatu dilakukan secara sistematis dan berkelanjutan. Tujuan evaluasi adalah menentukan kualitas daripada sesuatu, terutama yang berkaitan dengan nilai dan arti.

Dalam proses evaluasi harus ada pemberian pertimbangan (judgment). Melalui pertimbangan ini ditentukan nilai dan arti dari sesuatu yang sedang dievaluasi. Pemberian pertimbangan tentang nilai dan arti haruslah berdasarkan kriteria tertentu. Artinya harus terdapat kriteria yang jelas. Pertimbangan berdasarkan kriteria dapat berasal dari apa yang dievaluasi itu sendiri (internal), maupun berasal dari luar apa yang dievaluasi (eksternal). Evaluasi dimaksudkan sebagai bentuk asesmen atau pengecekan sejauh mana hasil uji coba dari model pendidikan, dalam hal ini evaluasi dalam Internalisasi Nilai-nilai Moderasi PAI di UPI.

Lukman Hakim telah melakukan penelitian tentang Internalisasi PAI di SDIT alMuttaqin Tasikmalaya yang dikaitkan dengan perilaku dan sikap siswa. Informan penelitian ini meliputi wakil kepala sekolah, siswa, orang tua siswa dan guru PAI di SDIT tersebut. Studi ini menggunakan metodologi kualitatif naturalistik. Temuan riset tersebut antara lain, pertama, kurikulum SDIT meng-gunakan kurikulum Kemendikbud, Kemenag, dan kurikulum institusional. Kedua, proses internalisasi dilakukan dengan cara mem-bujuk dan membiasakan, menumbuhkan ke-sadaran, menunjukkan disiplin dan kepatuhan aturan sekolah. Permodelan pembelajarannya adalah cerita, ibrah, tanya jawab, out-bond, cerita, nasihat, tugas, dan bernyanyi. Ketiga, penggunaan model kurikulum internalisasi nilai-nilai PAI di SDIT al-Muttaqin memberikan nilai positif bagi siswa dalam hal sikap dan perilaku siswa, yakni dapat meningkatkan ketaatan kepada Allah SWT, dan berperilaku yang santun terhadap sesama dan lingkungan.

Penelitian lainnya dilakukan oleh Rizka Fatmawati, merupakan tesisnya di UIN Yogyakarta dengan judul "Internalisasi NilaiNilai PAI Melalui Sistem Full Day School di TKIT Nurul Islam Yogyakarta". Penelitian ini didasari karena kasus lemahnya pemahaman internalisasi PAI mengakibatkan berbagai dimensi kekacauan moral orang dewasa, remaja, bahkan anak-anak. Pendidikan sebagai wahana internalisasi agama Islam dalam menghadapi demoralisasi generasi muda untuk membentuk moralitas yang baik di masa depan. Generasi muda nantinya mempunyai kecerdasan spiritual, dan intelektual. Penelitian menggunakan metode kualitatif.

Penelitian ini menemukan berbagai internalisasi PAI di kalangan siswa TKIT Nurul Islam Yogyakarta. Internalisasi, dan proses lainnya dilakukan dengan model moral knowing, moral feeling, dan moral action. Hasil internalisasi ini diimplementasikan melalui full day school yang bersifat integrated system terhadap semua unsur pendidikan. Proses pelaksanaan internalisasi berupa pembelajaran, habituasi, edukasi sikap, tindakan, dan permainan edukatif serta melalui 
sarana-sarana lainnya yang men-dukung keberhasilan internalisasi anak siswa sehingga memahami konsep PAI. Internalisasi tersebut meliputi aspek akidah, ibadah dan akhlak, serta melakukan aktivitas pendidikan dan bermain dengan berlandaskan moral yang baik, santun, dan berjiwa toleran. Implementasi dari internalisasi PAI melalui full day school menjadikan guru lebih dekat, lebih akrab, dan komunikasi lebih lancar dengan anak didik.

Sementara itu, Qowaid (2013 dan 2016) telah menulis tentang gejala intoleransi di kalangan peserta didik SMA dan SMK (2013) dan internalisasi pendidikan karakter pada siswa SMA (2016). Setelah mengkaji dua hasil riset di atas, terlihat bahwa kajian yang pertama berbicara internalisasi PAI di tingkat SD, dan yang kedua di tingkat TK. Sementara yang ketiga untuk tingkat SMA, baik tentang internalisasinya maupun gejala intoleransinya. Yang satu lokus risetnya di daerah Tasikmalaya, dan yang kedua di wilayah Yogyakarta. Sementara lainnya di Semarang dan berbagai daerah di Jawa dan Sulawesi. Hasil dari kajian masing-masing terfokus pada aplikasi internalisasi pada peserta didik di usia kanak-kanak dan siswa tingkat menengah. Sementara yang menjadi lokus penelitian ini lebih terfokus pada lingkungan mahasiswa yang secara usia sudah dewasa, dan mereka sudah pernah diedukasi pada jenjang pendidikan di Sekolah Menengah Atas atau yang sederajat dan tingkat di bawahnya.

\section{METODOLOGI}

Penelitian ini menggunakan pendekatan kualitatif. Adapun teknik pengumpulan data menggunakan observasi partisipatif, studi dokumentasi, dan wawancara. Observasi partisipatif yaitu peneliti mengamati apa yang dikerjakan obyek penelitian dalam hal ini mahasiswa dan dosen PAI di UPI, dengan mendengarkan apa yang mereka ucapkan, dan berpartisipasi dalam aktifitas mereka. Observasi dilaksana-kan melalui beberapa tahapan, di antaranya adalah observasi awal, dilaksanakan sebelum penelitian dilaksanakan. Dilakukan dengan pengamatan yang dilaksanakan di lokasi penelitian. Pengamatan dilakukan di kelas pada saat pembelajaran PAI dan seminar PAI serta saat pelaksanaan kegiatan tutorial PAI di UPI. Lokus penelitian ini di Kampus UPI.

Studi dokumentasi dilakukan pada saat sebelum dan saat pelaksanaan penelitian, seperti pada saat wawancara dengan para narasumber dan pelaksanaan obsesrvasi di kelas. Media yang digunakan dalam melakukan dokumentasi di antaranya menggunakan handycam, foto, dan tulisan (buku, jurnal, dan dokumen lain) dalam menunjang ketercapaian penelitian ini. Wawancara dilakukan terhadap narasumber yang berkompeten untuk menjawab permasalahan dalam penelitian ini. Proses wawancara dilaksanakan pada bulan September 2018 terhadap para dosen Tim Pengajar PAI di Kampus, mahasiswa PAI, dan Tutor PAI UPI angkatan 2018.

\section{HASIL DAN PEMBAHASAN}

Sebagaimana masalah dan tujuan, hasil dan pembahasan ini difokuskan pada 5 aspek. Kelima aspek tersebut adalah pola internalisasi nilai-nilai moderasi PAI di UPI, materi dalam internalisasi, kurikulum pelaksanaan internalisasi, metode internalisasi nilai-nilai, dan evaluasi dalam internalisasi. Pola internalisasi nilai-nilai moderasi melalui mata kuliah PAI di UPI dilakukan antara lain dengan cara memberikan pembelajaran kepada mahasiswa UPI tentang metodologi Pemahaman Islam. Hal ini dilakukan dalam upaya memberikan edukasi tentang arti penting menghargai perbedaan pendapat di kalangan mahasiswa atau ikhtilaf. Sedangkan UPI adalah sebuah perguruan tinggi negeri yang kampus utamanya berkedudukan di Kota Bandung, Jawa Barat, Indonesia. Sejak tahun 2012, UPI berstatus sebagai PT yang diselenggarakan pemerintah (PTP), berubah dari status sebelumnya sebagai Perguruan Tinggi Badan Hukum Milik Negara (BHMN). UPI adalah PT yang menganut sistem multikampus yaitu dengan 6 kampus yang tersebar di dua provinsi yaitu Jawa Barat dan Banten.

Pembelajaran dari Metodologi Pemahaman Islam seperti dijelaskan di atas mempunyai tujuan pembelajaran sebagai berikut: pertama mahasiswa memahami urgensi metodologi dalam memahami Islam. Kedua, memahami ketentuan-ketentuan atau 
rambu-rambu dalam memahami Islam. Ketiga, bersikap hati-hati dari pemahaman dan pengembangan ajaran Islam yang tidak ditunjang oleh metodologi yang benar. Keempat, pengembangan pemahaman terhadap Islam sesuai dengan bimbingan metodologi yang benar, dan kelima, bersikap terbuka untuk mendengar berbagai pemikiran dan pemahaman dan mampu memilah serta bersikap positif dan benar. (wawancara dengan Aam Abdussalam, Ketua Prodi PAI di UPI Bandung, pada hari Rabu tanggal 5 September 2018).

Secara umum bahwa pola internalisasi nilai-nilai moderasi PAI UPI dilakukan melalui, pertama: keberadaan mata kuliah PAI, di mana secara konten mata kuliah memang diarahkan dalam pembentukan karakter moderat bagi mahasiswa. Hal tersebut secara tersurat diajarkan dalam bab yang berkorelasi dan terkait langsung dengan pembentukan karakter mahasiswa moderat. Kedua dilakukan melalui keteladanan yang dilakukan seluruh pemangku kepentingan dan kebijakan di UPI khususnya Dosen PAI yang selalu mengedepankan sikap moderat. Hal ini sangat penting karena bagaimana kualitas pembentukan karakter mahasiswa diawali terlebih dahulu oleh Pendidik, karena seorang pendidik merupakan role model bagai mahasiswanya. Hal tersebut tercermin dalam proses pembelajaran secara langsung, dalam berkomunikasi dengan mahasiswa maupun kegiatan sehari-hari lainnya. Di samping itu, Menurut Asep Zainal Ausop, proses internalisasi atau menjadikan mahasiswa memahami nilai-nilai Islam ada empat macam; mindset atau pola pikir, behavior change atau perubahan perilaku, attitude change atau perubahan sikap, dan society change atau perubahan sosial budaya. (Seminar Hasil Penelitian Internalisasi Nilai-nilai Moderasi Islam melalui Mata Kuliah PAI di PTU, Bandung,1 November 2018).

Ada beberapa hal terkait materi dalam internalisasi nilai-nilai moderasi melalui mata kuliah PAI di UPI. Dalam hal ini Prof. Dr. Abas menjelaskan bahwa peranan masjid kampus UPI bernama Masjid al-Furqan jelas sangat strategis dalam mengedukasi karakter mahasiswa yang moderat. Hal penting, yang tidak bisa dikesampingkan dalam pencapaian moderasi nilai-nilai pendidikan karakter adalah dukungan pimpinan dari UPI sendiri, dalam hal ini dukungan dari Rektor sangat mewarnai pendidikan dari internalisasi nilai-nilai pendidikan karakter di UPI. (Wawancara dengan Abas Asyafah, Ketua Prodi PAI UPI, Kamis 6 September 2018).

Dengan materi-materi tersebut dapat dipantau pembinaan mahasiswa secara berjenjang. Dengan menunjuk ketua-ketua kelompok dari kalangan mereka (mahasiswa), dan dosen hanya berkomunikasi dengan para ketua kelompok. Dengan kegiatan ini maka diharapkan perkembangan para mahasiswa dalam hal ibadah dan kemampuan baca Alquran. Kegiatan ini juga disebut dengan pola pembinaan berjenjang, atau tutor sebaya. Bedanya dengan tutorial di depan, maka tutor sebaya lebih intens dalam mengetahui nilainilai internalisasi edukasi PAI ini.

Kurikulum dalam kajian ini adalah kurikulum pendidikan PAI di PTU dalam hal ini di UPI Bandung. Kurikulum PAI di UPI secara substansi mencakup Metodologi memahami Islam, Manusia dan agama, Islam sebagai Rahmatan lil âlamîn, Alquran: sumber pertama ajaran Islam, Hadis: sumber kedua ajaran Islam, ijtihad: proses pengembangan hukum Islam, Pembinaan Iman dan Takwa, Pembinaan Ibadah dan Akhlak, Pernikahan dan Pendidikan Keluarga, Pengelolaan dan pemanfaatan harta, Halal Haram dalam Islam, Mazhab dan aliran pemikiran dalam Islam, Dakwah, amar ma'ruf nahi munkar, dan jihad, Isu-Isu Kontemporer. (Koordinatoriat MK PAI UPI : 2018)

Aam menjelaskan bahwa dalam pelaksanaan Pendidikan PAI di UPI dimulai dengan kegiatan Pra Tes Baca Alquran yang dilakukan oleh tim tes yang disebut dengan tim tutorial yang dibentuk oleh tim dosen PAI. Anggota tim tes ini terdiri dari para mahasiswa yang lulus saringan untuk menjadi tim tutorial. Biasanya pada setiap angkatan diambil 5 sampai 10 orang berprestasi dari mahasiswa yang mengikuti kuliah PAI dalam tahun sebelumnya. Kuliah PAI untuk semester 2018 di kampus UPI secara efektif dilakukan pada tanggal 10 September 2018. 
Selain Pra tes, Tutorial menjadi pra syarat kelulusan mahasiswa peserta mata kuliah PAI di UPI. Tutorial dilakukan sebanyak 12 minggu, dan biasanya dilakukan pada waktu asar hingga waktu magrib. Pelaksanaan kuliah PAI di UPI diselenggarakan pada semester satu dan dua, dalam 2 satuan kredit semester. Setelah itu ditambahkan dengan Seminar PAI (SPAI) dengan bobot 2 satuan kredit semester juga, yang biasanya diberikan pada semester 5 dan 6 bagi mahasiswa Prodi PAI. Sehubungan dengan kegiatan Tutorial di UPI, Dr. Aam menjelaskan bahwa kegiatan tersebut diawali dengan Tes Baca Alquran, kemudian kajian terkait akidah dan syariah. Berikutnya tentang wawasan mahasiswa peserta tutorial untuk memastikan mereka tidak terpapar paham radikalisme atau ekstrem. Dan yang terakhir adalah materi tentang wawasan kebangsaan para mahasiswa peserta PAI di UPI .

Adapun dalam materi yang dimuat dalam kurikulum PAI sendiri, secara langsung terkait dengan pembentukan karakter mahasiswa yang moderat, di antaranya bisa dilihat dalam struktur kurikulum yang digunakan pada mata kuliah PAI di UPI (RPS PAI UPI). (Wawancara dengan Aam Abdussalam, dan Saepul Anwar, Rabu 5 September 2018).

Selain penjelasan di atas Dr. Aam menjelaskan tentang metode-metode internalisasi nilai-nilai Moderasi PAI di UPI dengan beberapa metode sebagai berikut: diskusi dengan mahasiswa tentang pemahaman mereka terhadap isu-isu yang terjadi di masyarakat. Kemudian mahasiswa diminta membuat riset lapangan, dan melaporkannya di depan kelas. Dosen berperan untuk mendengarkan penjelasan mahasiswa, dan jika ada hal-hal yang menyimpang, dosen memberikan penjelasan yang sebenarnya.

Jika ada dari kalangan mahasiswa yang mempunyai pemahaman yang sedikit radikal, maka tugas dosen memberikan penjelasan apa kekeliruan pemahaman mereka, kemudian meluruskan pemahaman itu. Sehingga mahasiswa bisa menyadari dari kekeliruan pemahaman mereka terhadap naskah ayat Alquran atau hadis nabi, seperti tentang pemahaman terhadap ayat yang menjelaskan tentang memerangi kafir, maka yang dimaksud dengan kata "hum" dalam ayat tersebut adalah mereka yang memerangi umat Islam. Jadi kafir yang tidak memerangi Islam itu tidak perlu diperangi. Inilah metode pemahaman Islam Wasathiah di kalangan mahasiswa PAI di UPI. Demikian pemaparan (Wawancara dengan Aam dan Saepul Anwar 5 September 2018).

Secara khusus, metode yang digunakan dalam internalisasi nilai-nilai moderasi dalam pembentukan karakter mahasiswa yang moderat dilakukan dengan melalui Mata Kuliah PAI di UPI, melalui Program Tutorial, melalui Pembinaan Unit Kegiatan Mahasiswa, dan melalui kegiatan lain yang menunjang tercapainya nilai-nilai moderasi bagi Mahasiswa. Berikut dijelaskan rinciannya.

Penyelenggaraan PAI di UPI berpedoman pada Peraturan Rektor UPI no. 5805/UN40/HK/2015 tentang Pedoman Penyelenggaraan Pendidikan UPI Tahun 2015. Dalam peraturan rektor tersebut salah satu bentuk implementasi kebijakan pemerintah tentang agama sebagai kurikulum wajib di pendidikan tinggi dilaksanakan UPI melalui dua mata kuliah agama dengan total 4 satuan kredit semester. Rinciannya adalah bahwa mata kuliah Pendidikan Agama diberikan pada tingkat pertama dan mata kuliah Seminar Pendidikan Agama yang bisa dikontrak oleh mahasiswa minimal pada tingkat tiga. Khusus untuk mahasiswa yang mengontrak mata kuliah PAI, diwajibkan untuk mengikuti kegiatan Tutorial PAI di Islamic Tutorial Center (ITC) setiap hari Minggu atau Sabtu dan wajib mampu membaca Alquran dengan baik dan benar. Kedua hal tersebut dijadikan pra syarat kelulusan mata kuliah PAI. Sementara untuk mahasiswa yang mengontrak mata kuliah SPAI mulai tahun 2013, diwajibkan mengikuti kegiatan Tutorial SPAI setiap hari Rabu dan atau Jumat setalah Salat Asar. (Kosasih, Fahrudin, \& Anwar, 2008)

Berkaitan dengan definisi, visi dan misi MK-PAI, sebagaimana dalam naskah silabus, maka MK-PAI (Koordinatoriat PAI dan SPAI UPI, 2016) di UPI bertujuan untuk: a). Mengembangkan kemampuan mahasiswa dalam memahami pokok-pokok ajaran agama Islam. b). Mengembangkan kemampuan mahasiswa dalam menerapkan ajaran Islam 
sebagai sumber nilai dan landasan berpikir serta berperilaku dalam ilmu dan profesi yang digeluti; dan Mengembangkan kemampuan mahasiswa dalam menyelesaikan masalah keagamaan dasar dalam kehidupan sehari-hari.

Sementara MK-Seminar PAI (Koordinatoriat PAI dan SPAI UPI, 2016) bertujuan untuk: a). Mengembangkan wawasan mahasiswa tentang ajaran Agama Islam dengan berbagai fenomena dan permasalahannya yang muncul dalam kehidupan. b). Mengembangkan kemampuan mahasiswa untuk menjadikan Islam sebagai sumber nilai, pedoman hidup dan landasan berpikir dan berperilaku dalam menerapkan ilmu dan profesi, dan c) Mengembangkan kemampuan mahasiswa untuk menjadikan nilai-nilai Islam sebagai "intellectual capital" dalam memecahkan problema-problema sosial secara kritis dan ilmiah.

Menurut A. Hassan, keteladanan merupakan tugas pokok pendidik dalam mengajar dan mendidik anak-anak. Hal ini sesuai dengan kesepakatan pakar pendidik mengenai urgensitas keteladanan. sebagai metode paling efektif dalam mendidik. Dalam hal ini Allah pun telah menegaskan bahwa keteladanan yang paling sempurna ada diri Rasulullah shallallahu 'alaihi wa sallam sebagaimana firman-Nya di dalam Alquran surah al-Ahzab ayat 21. Senada dengan A. Hassan, Hadratul Syaikh Hasyim Asy'ari pendiri Nahdlatul 'Ulama - pun menegaskan bahwa orang 'âlim (berilmu) seyogianya menjauhi hal-hal yang bisa menimbulkan tuduhan buruk, meskipun peluangnya kecil. Orang 'âlim tidak boleh melakukan suatu perbuatan yang berpotensi merendahkan harga dirinya dan diingkari secara lahiriah, meskipun diperkenankan secara bathiniyah. Aspek lain yang menarik dari pendidikan adab menurut A. Hassan adalah pendidikan kejujuran. A. Hassan di dalam bukunya, "Hai Poetrikoe" amat menekankan metode pendidikan dengan pendekatan kejujuran. Di antara adab yang sangat ditekankan beliau adalah: a) Kedisiplinan b) Keteladanan c) Mendidik dengan nilai kejujuran d) Pembiasaan dengan nasehat yang baik e) Pembelajaran di luar kelas dan sekolah f) Cinta buku g) Dialog dengan peserta didik.
Kegiatan Tutorial di UPI sebagai satu kesatuan program pembelajaran PAI dan SPAI, diadakan berdasar kesadaran perlunya PAI menyentuh aspek pembinaan kepribadian mahasiswa, dosen-dosen PAI di UPI merancang strategi pembelajaran PAI berbasis Tutorial. Pada awal sejarahnya Tutorial ini diharapkan agar mahasiswa IKIP (UPI saat itu) menjadikan masjid Alfurqon sebagai centre kegiatan mahasiswa dan juga Syi'ar islam (Suryana, 2009). Program Tutorial juga dapat dijadikan sebagai media pembinaan kepribadian mahasiswa, tutorial PAI merupakan proses pembinaan nilai-nilai agama Islam yang dilakukan melalui diskusi, dialog, dan penciptaan suasana keagamaan dengan menggunakan mesjid sebagai tempat kegiatan. Karena itu, kegiatan tersebut mendukung terciptanya iklim pendidikan PT yang menunjang terciptanya proses pendidikan yang sarat dengan penghayatan nilai-nilai religious (Penyelenggara Tutorial PAI/SPAI UPI, 2017). Setidaknya kegiatan tutorial berkontribusi terhadap upaya menumbuhkan dan membina kepekaan beragama mahasiswa (Anwar: 2017). Berikut disajikan alur PAI di UPI (Gambar 1).

Hal yang tidak kalah pentingnya dalam internalisasi nilai-nilai moderasi dalam pembentukan karakter mahasiswa moderat di antaranya adalah pembinaan yang dilakukan khususnya pembinaan terhadap kegiatan UKM UPI. UKM sebagai pusat kegiatan seluruh mahasiswa UPI merupakan satu wadah mahasiswa dalam mewadahi minat dan bakat mahasiswa khususnya dalam berorganisasi. Dengan banyaknya UKM dengan berbagai aliran, seperti UKM rohis, olahraga, penelitian, pers dan lainnya ditambah mereka sangat terbuka dengan siapapun termasuk pihak luar sekalipun, UPI konsen dalam membina nilai moderasi bagi mahasiswa. Seluruh UKM di UPI secara operasional berada di bawah Direktorat Kemahasiswaan ,di mana Direkturnya merupakan salah satu Dosen PAI UPI.

Kegiatan lain yang menunjang dalam mewujudkan karakter mahasiswa moderat di UPI, dilakukan dalam bentuk launching, seminar, dan lain sebagainya. Launching Gerakan Bahaya Radikalisme. Gerakan ini diluncurkan pada kegiatan penerimaan mahasiswa baru yang dihadiri ribuan 
mahasiswa peserta masa orientasi kampus dan kuliah umum (MOKAKU). Dalam kegiatan MOKAKU tersebut terdapat bentuk kuliah umum tentang bahaya radikalisme. Juga dilakukan seminar-seminar tentang bahaya radikalisme di UPI. Seminar ini cukup banyak membahas bahaya radikalisme di kampus khususnya. Seperti Seminar yang dilakukan Prodi Bahasa Arab FPBS dengan judul "Cegah Radikalisme dengan Deradikalisasi" dan kegiatan lainnya. Di Prodi PAI juga pernah diadakan kegiatan serupa tentang pentingnya nilai moderat dalam beragama.

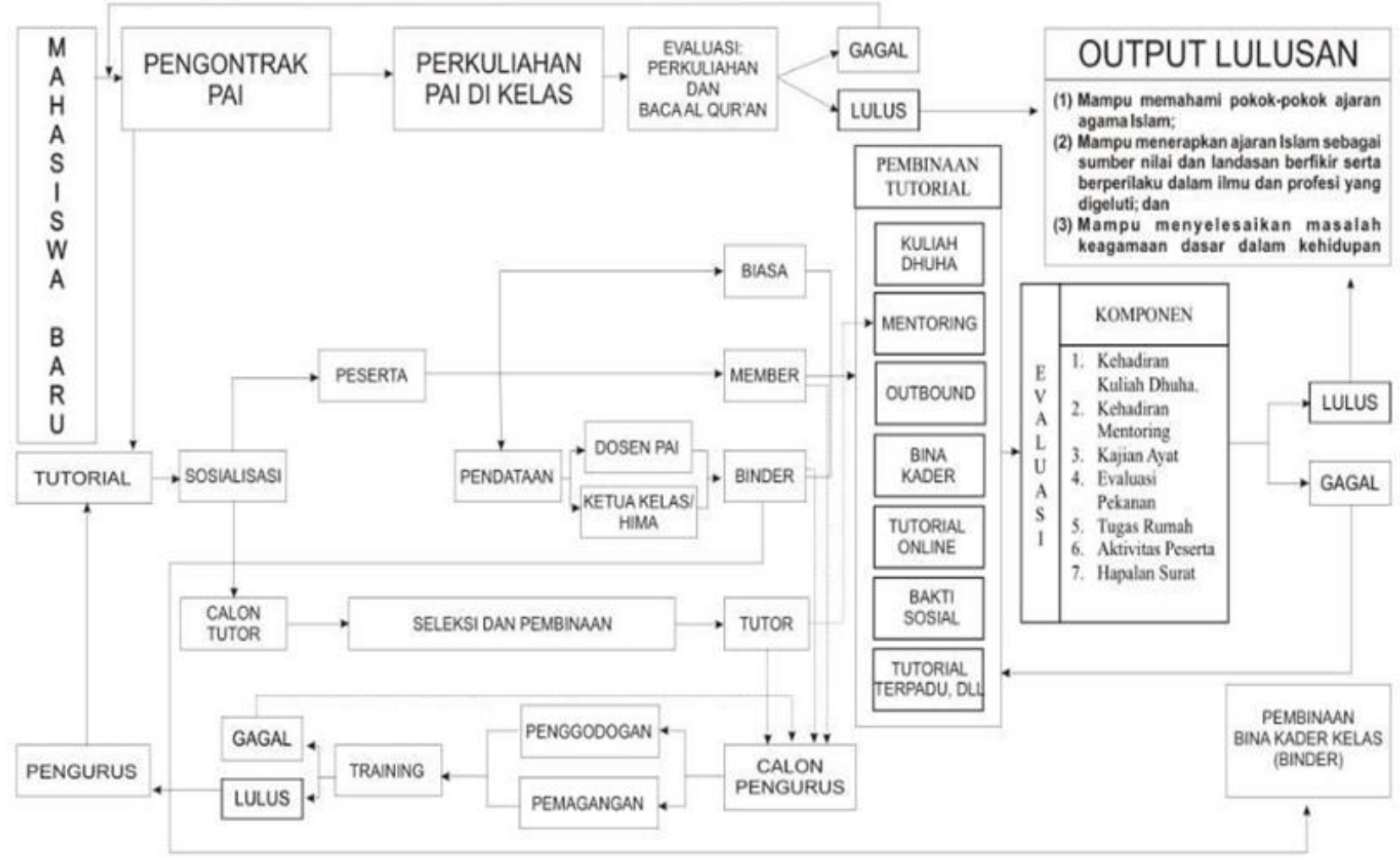

Gambar 1. Alur pendidikan pendidikan agama Islam di UPI Bandung

Dalam evaluasi dalam internalisasi, maka Computer Base Test (CBT) merupakan salah bentuk evaluasi bagi mahasiswa yang mengikuti Mata Kuliah PAI di UPI. Tes ini bertujuan untuk mengetes kamampuan kognitif mahasiswa PAI di UPI. Jumlah soal biasanya terdiri dari 50 soal multiple choice. Baik berupa sebab akibat, atau pilihan berganda. Bobot nilai dari CBT dapat disamakan dengan Ujian Akhir Semester di PT lain, seperti ITB, UI, dan PT lainnya. Kemudian hasil review dari ketua-ketua kelompok per kelas yang diambil dari mahasiswa-mahasiswa peserta Mata Kuliah PAI lainnya.

Selain CBT, ada juga evaluasi berupa Ujian Tengah Semester, Seminar PAI (SPAI), yang diselenggarakan pada hari Jumat dan hari Rabu, ba'da asar, dengan waktu sekira 2 jam per pertemuan. Kegiatan SPAI dengan cara mengumpulkan wakil-wakil kelas masingmasing. Mereka mengetengahkan makalah- makalah yang ditulis berdasarkan hasil riset mereka yang ditugaskan oleh dosen PAI di awal perkuliahan. Tutorial menjadi syarat kelulusan mahasiswa. Adapun indikator penilaian internalisasi moderasi PAI di UPI ada beberapa indikator dalam berbagai tingkat yakni Tingkat Mahir, Tingkat, Tingkat Dasar Satu, Tingkat Dasar Dua, dan Tingkat Pra dasar Satu. Inilah indikator-indikator evaluasi nilai-nilai moderasi, dengan menggunakan metode Baki (bil hikmah).

Dari berbagai uraian di atas maka dapat dianalisis lebih lanjut sebagai berikut. Proses internalisasi nilai-nilai moderasi melalui mata kuliah PAI di UPI, pada dasarnya dilakukan secara komprehensif. Dalam hal ini proses pemasukan nilai-nilai moderasi tersebut dilakukan melalui berbagai pendekatan. Ujung tombak dari keberhasilan internalisasi nilainilai moderasi tersebut di antaranya faktor kebijakan kampus UPI di mana 
mengeksplisitkan mata kuliah PAI menjadi dua mata kuliah umum wajib, yakni melalui mata kuliah PAI dan Seminar PAI seluruhnya sebanyak 4 satuan kredit semester. Hal ini berbeda dikarenakan di kampus lain mungkin hanya memuat dua satuan kredit semester saja yakni PAI saja. Hal tersebut tidak terlepas dari kebijakan UPI sendiri untuk menambah bobot mata kuliah ini dengan penambahan mata kuliah seminar PAI di semester selanjutnya (kelulusan mata kuliah PAI sebagai prasyarat).

Adapun kurikulum yang digunakan dalam proses internalisasi nilai-nilai moderasi PAI di UPI dibuat sedemikian rupa di mana salah satu tujuan dari mata kuliah tersebut yakni pemahaman nilai-nilai moderasi di kalangan mahasiswa. Materi yang dilaksanakan dalam menunjang keberhasilan mata kuliah ini, di awali dengan screening penguasaan mahasiswa tentang membaca Alquran. Hal ini bertujuan untuk pemetaan kemampuan mahasiswa dalam kemampuan membaca Alquran, karena hal tersebut akan menunjang kemampuan mahasiswa dalam mendalami Alquran secara komprehensif.

Materi yang diamanahkan dari kurikulum sendiri secara tersurat terdapat dalam konten materi PAI di UPI yang bertujuan terhadap internalisasi nilai-nilai moderasi bagi mahasiswa. Dari RPS yang digunakan saat ini, dapat dilihat materi kurikulum PAI yang secara langsung menunjang dalam tercapainya tujuan mata kuliah ini, di antaranya: materi satu tentang metode memahami Islam yang tepat, materi keempat tentang "ijtihad" sebagai proses pengembangan hukum Islam dan ragam persoalan khilafiyah dalam Islam, materi kesepuluh tentang konsep akhlak dan pengaplikasiannya dalam berperilaku, materi sebelas tentang konsep dakwah dan amar ma'ruf nahi munkar dalam Islam dan implementasinya dalam kehidupan sehari-hari, materi keduabelas tentang konsep jihad dalam Islam dan perwujudannya dalam kehidupan sehari-hari.

Melihat kekhususan dari mata kuliah SPAI di atas dan berpijak pada tujuan kedua dari pendidikan agama, sebagaimana yang diutarakan Harris \& Morrran (1998), maka perlu dilakukan pendekatan atau model berbeda dengan mata kuliah PAI sebelumnya.
Model pembelajaran yang dikembangkan adalah model pembelajaran berbasis riset yang bermula dari permasalahan yang aktual. Dengan model tersebut mahasiswa diarahkan untuk memiliki kepekaan terhadap persoalan keagamaan yang sedang in di masyarakat, khususnya yang berkaitan secara langsung dengan bidang keahlian mereka dan melakukan riset dengan cara survei, observasi atau wawancara dan teknik-teknik lainnya. Hasil riset mereka kemudian diseminarkan di kelas dalam perkuliahan tatap muka (Asyafah \& Anwar, 2016)

Penguatan melalui keberlangsungan mata kuliah ini senada dengan apa yang diungkapkan Budimansyah dalam Farida (2012) model karakter di PT dilakukan melalui salah satu dari tiga modus, yakni melalui penguatan pendidikan kewarganegaraan dalam kapasitasnya sebagai mata kuliah wajib umum yang menjadi menu wajib bagi seluruh mahasiswa. Mata kuliah PAI dan SPAI dipilih karena melalui mata kuliah ini pengembangan karakter akhlak Islam, yakni mahasiswa memiliki dan mengamalkan karakter Islam seperti toleransi.

Menurut Lindholm and Astin, 2008 dalam Furqon (2016), pendidikan yang berbasis spiritualitas Islam sejatinya bertujuan menghasilkan kecerdasan emosional dan istilah yang kini berkembang yaitu, kecerdasan adversitas (Adversity Intelligence), suatu kecerdasan atau ketahanan seseorang dalam menghadapi permasalahan hidupnya. Banyak riset yang menunjukkan adanya hubungan yang kuat antara spiritualitas dengan kapasitas seseorang dalam hubungannya dengan dunia di sekitarnya, yang tercermin dalam bentuk empati, sikap etis, tanggung jawab sosial, semangat dan peduli terhadap keadilan sosial.

Tujuan dari pengembangan karakter mulia seperti pengamalan sikap moderat sebagaimana apa yang dicita-citakan di atas, sangatlah penting dalam menopang kehidupan keberagamaan di Indonesia khususnya mahasiswa. Memiliki sikap moderat bagi seluruh masyarakat Indonesia sebagai sebuah keharusan dalam meminimalisir dampak negatif dari bahaya radikalisme di Indonesia.

Kegiatan yang terintegrasi dengan dua mata kuliah di atas yakni PAI dan SPAI yang 
sangat urgen dalam pelaksanaannya adalah kegiatan Tutorial. Pentingnya kegiatan Tutorial ini sebagai bagian dari media pembinaan mahasiswa UPI. Tutorial sebagai media pembinaan kepribadian mahasiswa, tutorial PAI merupakan proses pembinaan nilai-nilai agama Islam yang dilakukan melalui diskusi, dialog, dan penciptaan suasana keagamaan dengan menggunakan mesjid sebagai tempat kegiatan. Karena itu, kegiatan tersebut mendukung terciptanya iklim pendidikan PT yang menunjang terciptanya proses pendidikan yang sarat dengan penghayatan nilai-nilai religius (Penyelenggara Tutorial PAI/SPAI UPI, 2017).

Dalam Program Tutorial UPI setidaknya ada beberapa kegiatan rutin yang dilaksanakan, yaitu untuk peserta tutorial berupa kuliah duha, mentoring, bina kader (binder), talkshow, mabit; untuk tutor tutorial berupa pendidikan tutor, pembinaan tutor, dan rihlah tutor; sementara untuk pengurus tutorial: upgrading pengurus, pembinaan pengurus, dan kajian rutin (Kosasih, Fahrudin, \& Anwar, 2008).

Tutorial sebagaimana yang ditujukan di atas, yakni sebagai media pembinaan nilai-nilai agama Islam yang berpusat di masjid. Dalam proses pelaksanaannya, tutor berperan dalam proses internalisasi nilai nilai karakter agama yang diinginkan. Peran tutor karena ia berperan dalam hampir seluruh kegiatan ini, seperti dalam mentoring ibadah, diskusi, mabit dan kegiatan lainnya. Pembinaan yang dilakukan ini sejatinya mengarahkan agar mahasiswa mengamalkan nilai karakter yang dicitakan, salah satunya adalah karakter moderat di kalangan mahasiswa. Dalam hal ini merupakan pelaksanaan prinsip uswiyah (keteladanan) dari seorang tutor bagi para anggotanya.

Prinsip uswiyah yang dimaksud adalah cerminan dari seorang tutor yang dipraktikkan dalam kesehariannya untuk kemudian menjadi inspirasi bagi anggotanya yang lain. Uswiyah yang dimaksud yakni seorang mualim (tutor) yang menampilkan diri dan seluruh perilakunya untuk menjadi rujukan bagi mu'allam (anggota) dalam pengembangan kepribadiannya sesuai dengan nilai-nilai yang diagungkannya (Abdussalam, 2017).

Kegiatan lain yang menunjang yakni pembinaan terhadap kegiatan UKM UPI.
Dengan banyaknya UKM dengan berbagai aliran, seperti UKM rohis, olahraga, penelitian, pers dan lainnya ditambah mereka sangat terbuka dengan siapapun termasuk pihak luar sekalipun, UPI konsen dalam membina nilai moderasi bagi mahasiswa. Khususnya UKM agama, untuk menyamakan kebijakan maka para dosen PAI membina secara langsung keberadaan UKM agama tersebut. Hal yang dikhawatirkan adalah ketika tidak dibina secara komprehensif oleh para Dosen, maka UKM agama ini sangat mudah untuk dimasuki atau dipengaruhi pihak lain yang tidak bertanggungjawab.

Terakhir yang tak kalah penting adalah proses evaluasi yang dilakukan dalam internalisasi nilai-nilai moderasi. Proses screening sebagai tahap awal mengetahui pemahaman mahasiswa sejak dini. Akan sangat membantu dosen dalam menginformasikan tahap deteksi awal jika dimungkinkan terdapat paham dan tindakan yang hendak mengarah pada sikap intoleran. Selanjutnya proses tutorial, monitoring yang dilakukan tutor sangat efektif dalam mendeteksi hal hal yang mengarah pada paham dan tindakan yang dimungkinkan menyimpang. Sejak dini para Tutor dapat melakukan pembinaan dan efek keberhasilan sangat efektif.

Hal ini penting untuk dicapai karena memiliki sikap moderat bagi seluruh masyarakat Indonesia sebagai sebuah keharusan dalam meminimalisir dampak negatif dari bahaya radikalisme di Indonesia. Secara etimologis, kata moderat (al-wasatiyah) merujuk pada tiga makna yaitu: pertama, bermakna kebaikan dan keadilan. Kedua, bermakna seimbang dalam segala hal. Sikap seimbang yang terlindungi dari sikap melebihkan (ekstrem kiri/ifrath) dan mengurangkan (ekstrem kanan/tafrith). Ketiga, memiliki makna berada di tengah atau di antara dua ujung sesuatu atau berada di tengah . tengah antara dua hal. (Dawood dkk, 2017).

\section{PENUTUP}

Pola internalisasi nilai-nilai moderasi PAI UPI dilaksanakan melalui: a). melalui keberadaan mata kuliah PAI, di mana secara konten berkorelasi langsung dengan 
pembentukan karakter mahasiswa moderat. b). Melalui keteladanan yang dilakukan seluruh pemangku kepentingan dan kebijakan di UPI khususnya dosen PAI yang selalu mengedepankan sikap moderat. Materi-materi yang disampaikan dalam internalisasi nilainilai moderasi PAI UPI dilakukan: a). terkait dengan input dari mahasiswa yang menjadi peserta kuliah PAI di UPI. b). Berkaitan dengan dosen pengampu mata kuliah PAI di UPI, baik terkait kemampuan mengajar, atau kompetensi-kompetensi dosen PAI UPI. c). Berkaitan dengan materi dari Mata Kuliah PAI itu sendiri. d). Berkaitan dengan dukungan dari lingkungan kampus UPI.

Kurikulum Pelaksanaan Internalisasi nilai-nilai moderasi PAI UPI dilaksanakan berdasar konten mata kuliah PAI sendiri yang berkorelasi dengan pembentukan karakter moderat mahasiswa, adapun konten kurikulum sesuai RPS mata kuliah PAI UPI 2018, di antaranya: (materi kesatu) metodologi memahami Islam, (materi keempat) ijtihad sebagai proses pengembangan hukum Islam dan ragam persoalan khilafiyah dalam Islam, (materi kesepuluh) konsep akhlak dan pengaplikasiannya dalam berperilaku, (materi kesebelas) konsep dakwah dan amar ma'ruf nahi munkar dalam Islam, (materi keduabelas) konsep jihad dalam Islam dan perwujudannya.

Metode internalisasi nilai-nilai moderasi PAI UPI, dilakukan: a). melalui mata kuliah PAI, b). melalui penguatan kegiatan integrasi Tutorial, melalui pembinaan unit kegiatan mahasiswa, dan d). melalui kegiatan lain yang menunjang tercapainya nilai-nilai moderasi bagi mahasiswa, seperti launching gerakan bahaya radikalisme di UPI, diadakan seminar tentang bahaya radikalisme, dan kegiatan lain yang menunjang. Evaluasi internalisasi nilainilai moderasi PAI UPI, dilaksanakan melalui: a) Screening wawasan mata kuliah PAI dengan metode computer base test. b) Laporan yang dilaksanakan para tutor pada pelaksanaan Tutorial. c) Laporan para dosen dan pihak lain.

\section{DAFTAR PUSTAKA}

Madjid, Abdul et al (2016) Pendidikan Agama Islam. Bandung: Departemen Pendidikan Umum FPIPS UPI.
Abdussalam, A. (2017) Pembelajaran dalam Islam. Yogyakarta : Maghza Pustaka.

Alim, M. (2006) Pendidikan Agama Islam Upaya Pembentukan Pemikiran dan Kepribadian Muslim. Bandung: PT. Remaja Rosdakarya.

Anshari, E.S. (1993) Wawasan Islam: Pokokpokok Fikiran tentang Islam dan Ummatnya, Edisi II Jakarta : CV Rajawali.

Anwar (2016). Peran Strategis Mata Kuliah Pendidikan Agama Islam dalam Menanamkan Nilai-Toleransi. Proseeding. Islamic Education Face Global Challenge. Bandung: Departemen Pendidikan Umum FPIPS UPI.

Arikunto, S. (2009) Manajemen Penelitian. Jakarta : Rieneke Cipta.

Azzahrah, et al (2018) 'Internalisasi Nilai Religius pada Rencana Pelaksanaan Pembelajaran (RPP) Muatan Lokal Bahasa Jawa di Lembaga Pendidikan.'Jurnal Pendidikan Agama dan Keagamaan.16(3)

Cecep Darmawan dalam Endang Soemantri. (2011). Pendidikan Karakter : Nilai Inti Bagi Upaya Pembinaan Kepribadian Bangsa. Bandung : Widya Aksara Press

Dawood,M.M.E, S. H dan S.Asofa. (2017). Moderat dan Prinsip Kemudahan. Yogyakarta: Idea Press

Etikasari, Nur Wahyu, Persepsi Mahasiswa Program Studi S1 Ppkn Universitas Negeri Surabaya Terhadap Wacana Intoleransi Di Media Sosial', Kajian Moral dan Kewarganegaraan 6, no. 01 (25 January 2018),

Farida, I. (2013) Model Pendidikan Karakter di Perguruan Tinggi: Langkah Strategis dan Implementasinya di Universitas. Lampung: UNILA.

Fatmawati,R. (2016). "Internalisasi nilai-nilai pendidikan agama islam melalui sistem full day school Anak Usia Dini di TK IT Nurul Islam Yogyakarta. Yogyakarta:UIN Yogyakarta 
Furqon. (2016). Ke Arah Pengembangan Pedagogi Spiritual. Proseeding : Islamic Education Faces Global Challenges.

Hakim,L. (2012) "Internalisasi Nilai-Nilai Agama Islam Dalam Pembentukan Sikap dan Perilaku Siswa Sekolah Dasar Islam Terpadu Al-Muttaqin Kota Tasikmalaya'. Jurnal Pendidikan Agama Islam- Ta'lim Vol. 10 No.1.

http://jurnalmahasiswa.unesa.ac.id/index.php/j urnalPendidikankewarganegaraa/article/v iew/22679.

Laisa, E. (2014) 'Islam dan Radikalisme' Jurnal Studi Islam Islamuna Vol 1 No 1 Juni 2014.

Kholid, AS Moh. "Menggalakkan (lagi) Pendidikan Toleransi". Media Indonesia, 14 Januari 2013.

Komalasari, K., D. Saripudin dan I.S. Masyitoh. (2014). Living Values Education Model in Learning and Extracurricular Activities to Construct the Students' Character. Journal of Education and Practice Vol. 5 No. 7 2014.

Kompas, 1 Juni 2013 "Indonesia Atasi Masalah Intoleransi".

Koordinatoriat PAI Departemen Pendidikan Umum FPIPS UPI Bandung. (2018), Rancangan Profil MKWU PAI di UPI. Tidak diterbitkan.

Ma'rifataini,L.(2018) 'Implementasi Metode Pembelajaran Pendidikan Agama Islam (PAI) Di Sekolah Menengah Atas Negeri (SMA) 11 Bandung'. Jurnal Penelitian Agama dan Keagamaan 16(1)

Maarif, M.A., 2019. Internalisasi Nilai Multikulutural Dalam Mengembangkan Sikap Toleransi (Studi Di Di Pesantren Mahasiswa Universitas Islam Malang). Nazhruna: Jurnal Pendidikan Islam, 2(1), pp.164-189.

Marten, R. (2012) Successful Coaching Fourth Edition. IL : Human Kinetics

Megawangi,R.2006. Membangun SDM Indonesia melalui Pendidikan Holistik Berbasis Karakter. Jakarta: Dir Pembinaan TK dan SD.
Nuraki Aziz. (2018).Temuan BNPT tentang Paparan Radikalisme di Sejumlah Universitas dipertanyakan.Tersedia pada: https://www.bbc.com/indonesia/indonesi a-44357353. (Diakses: 2 September 2018)

Nasution.S.(2003). Metodologi Penelitian Naturalistik Kualitatif. Bandung: Tarsito

Poerwadarminta,W.J.S. (2009). Kamus Umum Bahasa Indonesia Edisi Ketiga. Jakarta: Balai Pustaka

Sugiyono. (2009). Metode Penelitian Penelitian Kualitatif, Kuantitatif dan R\&D. Bandung: Alfabeta.

Suryana, T. (2009) Tutorial Handbook Pendidikan Agama Islam MKDU FPIPS UPI. Bandung: UPI.

Sulfemi, Wahyu Bagja. (2018) Pengaruh Disiplin Ibadah Sholat, Lingkungan Sekolah, dan Intelegensi Terhadap Hasil Belajar Peserta Didik Mata Pelajaran Pendidikan Agama Islam. Edukasi: Jurnal Penelitian Pendidikan Agama dan Keagamaan, 16 (2)

Qiqi Yuliati dan Rusdiana. (2014) Pendidikan Nilai; Kajian Teori dan Praktik di Sekolah. Bandung; Pustaka Setia.

Qodir, Z., Kaum Muda, Intoleransi, dan Radikalisme Agama. Jurnal Studi Pemuda, 5(1), pp.429-445.

Qowaid, Q., 2016. Character Education Through Religious Education In Sman 2 Semarang. Jurnal Dialog, 39(2), pp.209226.

Qowaid, Q., 2013. Gejala Intoleransi Beragama Di Kalangan Peserta Didik Dan Upaya Enanggulangannya Melalui Pendidikan Agama Islam Di Sekolah. Jurnal Dialog, 36(1), pp.71-86.

Wafi, Abdul (2017), Konsep dasar Kurikulum Pendidikan Agama Islam, Edureligia Jurnal Pendidikan Agama Islam. Vol. 1, No. 2, Juli - Desember 2017

Yaumi, M. (2016) Pendidikan Karakter : Landasan, Pilar dan Implementasi. Jakarta: Prenadamedia Group. 
Yunus,F.A.(2017) 'Radikalisme, Liberalisme, dan Terorisme : Pengaruhnya terhadap Islam' Jurnal Studi Alquran: Membangun Tradisi Berfikir Qur'ani.Vol.13 No. 1 Tahun 2017.
Zuchdi, D. (2008) Humanisasi Pendidikan Menemukan Kembali Pendidikan yang Manusiawi. Jakarta: PT Bumi Aksara. 